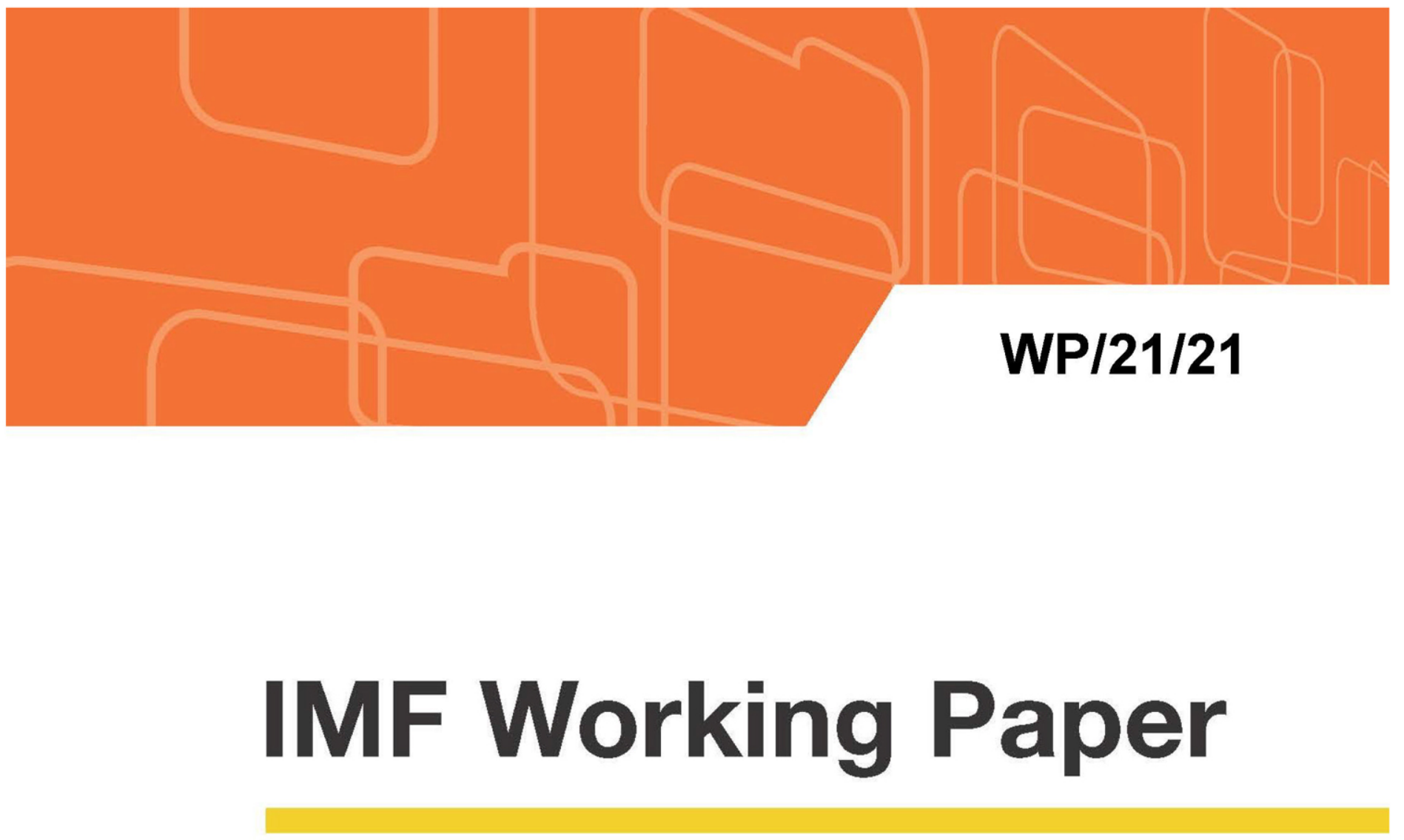

\title{
Social Repercussions of Pandemics
}

by Philip Barrett and Sophia Chen

IMF Working Papers describe research in progress by the author(s) and are published to elicit comments and to encourage debate. The views expressed in IMF Working Papers are those of the author(s) and do not necessarily represent the views of the IMF, its

Executive Board, or IMF management. 


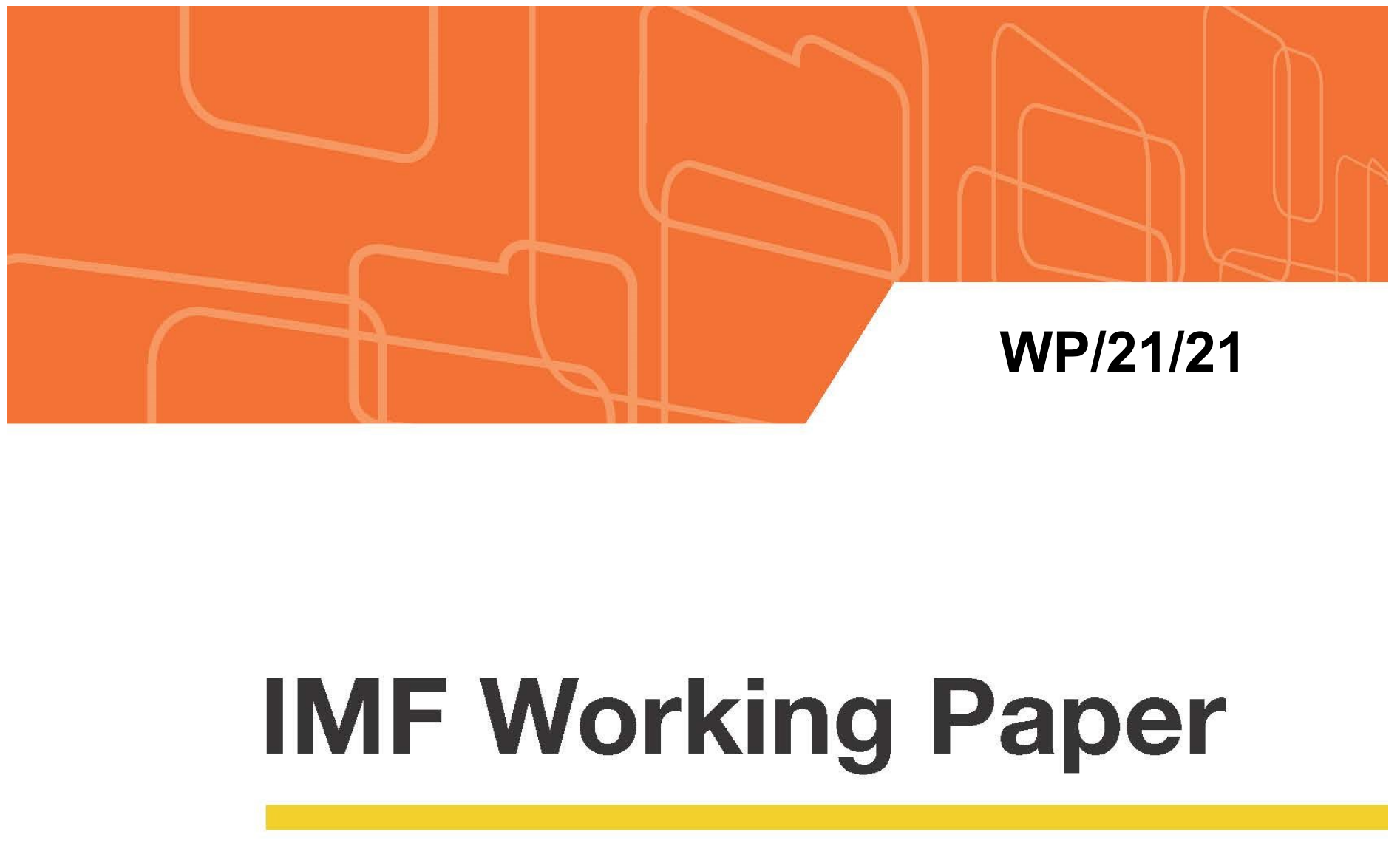

\section{Social Repercussions of Pandemics}

by Philip Barrett and Sophia Chen

IMF Working Papers describe research in progress by the author(s) and are published to elicit comments and to encourage debate. The views expressed in IMF Working Papers are those of the author(s) and do not necessarily represent the views of the IMF, its Executive Board, or IMF management.

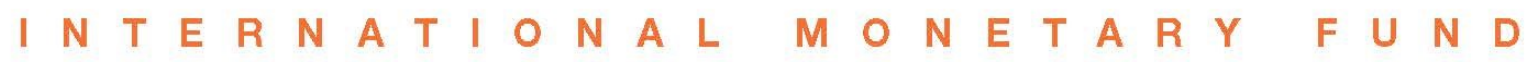




\title{
IMF Working Paper
}

Research Department

\section{Social Repercussions of Pandemics}

\section{Prepared by Philip Barrett and Sophia Chen ${ }^{1}$}

Authorized for distribution by Malhar Nabar

January 2021

\section{IMF Working Papers describe research in progress by the author(s) and are published to elicit comments and to encourage debate. The views expressed in IMF Working Papers are those of the author(s) and do not necessarily represent the views of the IMF, its Executive Board, or IMF management.}

\begin{abstract}
Epidemics may have social scarring effects, increasing the likelihood of social unrest. They may also have mitigating effect, suppressing unrest by dissuading social activities. Using a new monthly panel on social unrest in 130 countries, we find a positive crosssectional relationship between social unrest and epidemics. But the relationship reverses in the short run, implying that the mitigating effect dominates in the short run. Recent trends in social unrest immediately before and after the COVID-19 outbreak are consistent with this historic evidence. It is reasonable to expect that, as the pandemic fades, unrest may reemerge in locations where it previously existed.
\end{abstract}

JEL Classification Numbers: N30, N40

Keywords: COVID-19, crisis, disasters, epidemic, social unrest

Author's E-Mail Address: PBarrett@imf.org, ychen2@,imf.org

\footnotetext{
${ }^{1}$ We thank Deniz Igan, Gian Maria Milesi-Ferretti, Malhar Nabar, and Antonio Spilimbergo for helpful comments. Luisa Calixto provided excellent research assistance.
} 


\section{INTRODUCTION}

In 1832, the great cholera pandemic hit Paris. In just a few months, the disease killed 20,000 of the city's 650,000 population. Most fatalities occurred in the heart of the city, where many poor workers lived in squalid conditions, drawn to Paris by the Industrial Revolution. The spread of the disease heightened class tensions, as the rich blamed the poor for spreading the disease and the poor thought they were being poisoned. Animosity and anger were soon directed at the unpopular King. The funeral of General Lamarque - pandemic victim and defender of popular causes - spurred large anti-government demonstration on the barricaded streets: scenes immortalized in Victor Hugo's novel Les Misérables. Historians have argued that the epidemic's interaction with pre-existing tensions was a principal cause of what came to be known as the Paris Uprising of 1832, which may in turn explain subsequent government repression and public revolt in the French capital in the $19^{\text {th }}$ century (Snowden 2019).

From the Plague of Justinian and the Black Death to the 1918 Influenza Epidemic, history is replete with examples of disease outbreaks casting long shadows of social repercussions: shaping politics, subverting the social order, and some ultimately causing social unrest (North and Paul 1973, Bristow 2017, Elledge 2020). Despite ample examples, quantitative evidence on the link between epidemics and social unrest is scant and limited to specific episodes. This paper fills the gap. We examine whether epidemics may lead to higher likelihood of social unrest using global evidence in recent decades. Understanding the implications of epidemics on social unrest is crucial for preparing for potential social repercussions caused by the COVID-19 pandemic.

There are several ways in which epidemics could affect the likelihood of social unrest. On the one hand, epidemics, like other threats to human health such as natural disasters, can subvert the social order. Mishandling of epidemics may reveal deeper problems such as insufficient social safety nets, incompetent government, or the public's lack of trust in institutions. Outbreaks of contagious diseases have historically caused "fear of the other" and backlash against certain groups (Deverell 2004; Hogarth 2017; Randall 2019). And containment and mitigation efforts could be seen as excessive and unnecessarily costly ex 
post-ironically, this may happen if these efforts are successful in stopping the spread of a disease. Furthermore, possibly severe economic damage from epidemics, especially if affecting disproportionately the poor, could exacerbate inequality and sow the seeds of future social unrest. These are the scarring factors of epidemics that may give rise to social unrest.

On the other hand, epidemics are humanitarian crises that bring abrupt disruptions to lives. Such disruptions may impede the communication and transportation needed to organize major protests. Similarly, public opinion might favor cohesion and solidarity in times of duress. In some cases, incumbent regimes may also take advantage of an emergency to consolidate power and suppress dissent. As a result of these mitigating factors, the social scarring in the form of unrest may not show up quickly. For these reasons, the overall effect of epidemics on social unrest may depend on the horizon. Its quantitative impact is a priori ambiguous, depending on the offsetting effects of the scaring and mitigating factors at different horizons

Our analysis relies on a new cross-country dataset on social unrest - the Reported Social Unrest Index (RSUI). The RSUI is an index constructed based on press coverage of social unrest. Social unrest events are identified using spikes of the index. Barrett et al. (2020) show that these identified events line up very closely with narrative descriptions of unrest in a variety of case studies, suggesting that the index captures real events rather than shifts in media sentiment or attention. This approach provides a consistent, monthly measure of social unrest for 130 countries from 1985 to the present. It addresses a key challenge for research on social unrest on identifying when events of unrest have occurred, with extant sources of information mostly available at low frequency, with a significant time lag, or have incomplete coverage.

Using this social unrest dataset merged with a comprehensive dataset of epidemics around the world, we find that countries with more frequent and severe epidemics also experienced greater unrest on average. However, this cross-sectional relationship is likely not causal. For example, common factors, such as geography or income level may lead to more unrest and more or more serious epidemics. We thus also estimate a dynamic panel model. The causal 
interpretation of this model rests on the assumption that that the exact timing of epidemics is random. In other words, the likelihood of an epidemic outbreak at a given time does not vary systematically with other factors that may lead to unrest. This seems to be a reasonable assumption within a relatively short timeframe, as in our empirical setting.

The dynamic panel model shows that the likelihood of unrest following epidemics goes down. This suppressive effect is sufficiently large as to drive protest almost to zero in the average country. The COVID-19 experience is not included in our standardized epidemics dataset, and so serves as an out-of-sample test of our quantitative findings. It is so far consistent with this historical pattern, with an almost complete cessation of recorded unrest during the peak months of the crisis in spring 2020, followed by a slow recovery since. Our paper is related to a large literature on social and political instability. One strand of the literature examines the impact of social and political instability on growth, output, investment (Alesina and Perotti 1996; Alesina et al. 1996; Jong-A-Pin 2009; Aisen and Veiga 2013; Bernal-Verdugo et al. 2013; ), and stock market performance (Barrett et al, forthcoming). Miguel et al. (2004) find that economic growth is strongly negatively related to civil conflict: a negative growth shock of five percentage points increases the likelihood of conflict by onehalf the following year. A separate strand of the literature examines the determinants of social unrest. Ponticelli and Voth (2020) find a positive correlation between fiscal austerity and social unrest in Europe in the period between World War I and the Global Financial Crisis. Fearon and Laitin (2003) and Collier, Hoeffler, and Rohner (2009) find that poor policies and institutions are important determinants of social unrest among low-income countries (LICs) or other emerging and developing economies (EMDEs).

Empirical evidence on the relationship between epidemics and social unrest are scant. One exception is Cervellati et al (2014), who find that exposure to multi-host vector pathogen (e.g. Malaria, zika, yellow fever) affects the likelihood of civil wars, a particularly extreme form of social unrest. In another study, Cervellati et al (2018) find that a higher exposure to malaria increases the incidence of civil violence in African countries. Both papers focus on specific forms of unrest in Africa and explore cross-section variation in the exposure to a specific type of contagious diseases. In comparison, our paper offers broad-based evidence 
and explores both cross-sectional and time-series variations from the short-run to long-run horizons.

The rest of the paper is organized as follows. Section II describes the data and measures and present evidence on the recent trend of social unrest. Section III discusses the empirical methodology and results. Section IV concludes.

\section{DATA AND MEASUREMENTS}

\section{A. Measuring social unrest}

We use a newly constructed data on social unrest events based on the Reported Social Unrest Index (RSUI) (Barrett et al. 2020). The authors use articles from major international news sources to create the country specific RSUI. For each country, the RSUI is constructed using the number of articles on social unrest as a fraction of total articles. The authors use textbased criteria the to identify articles on social unrest. For example, relevant articles must include words such as "protest", "riot" or "revolution". They must also exclude certain terms to avoid counting reports about previous events or revolution-themed movies. The selected articles must be at least 100 words long and must mention the name of the country in question. At the country level, the RSUI exhibits very large spikes that are associated with major episodes of social unrest. The authors develop quantitative criteria to formalize these spikes and identify a list of social unrest events at the country-month frequency. ${ }^{2}$ They compare these events against consensus narratives for a number of case studies, showing that they align closely, and conclude that this method captures actual major social unrest events. The final dataset consists of 569 events in 130 countries from mid-1980s to early 2020 .

We merge the social unrest data with EM-DAT - a comprehensive database of international epidemics and natural disasters, with information on the timing and location of more than 11,000 events since 1990. Although our focus is on epidemics, we also collect data on five

\footnotetext{
${ }^{2}$ See Barrett et al. (2020) for multiple tests of this event coding against alternative narrative sources. The event dataset has several advantages over the index alone. It addresses the limitation in the RSUI construction that media coverage may not be fully comparable across countries. It also permits better cross-checks for false positives and permits a labelling of each event, thus facilitating event narratives.
} 
other types of disasters. Four types of disasters - floods, storms, earthquakes, and landslides - are, along with epidemics, the most common events in the sample.(online appendix Table A1). Droughts, although the only the seventh most common type of event appear have particularly extensive impacts, on average affecting ten times as many people as the next most far-reaching disaster, storms. The comparison to other disaster types is useful because, as discussed earlier, epidemics and natural disasters are both humanitarian crises that present similar challenges to social orders.

\section{B. Recent social unrest events}

\section{Social unrest pre-COVID-19}

Between January 2019 and January 2020, the events dataset identifies 59 unrest events in forty countries. A number of major protests occurred late 2019 to early 2020, most notably in the Middle East and South America but also elsewhere. None of these events appear to be directly linked to major natural disasters or epidemics. ${ }^{3}$ Instead, most of the unrest events were motivated by political factors. This recent wave of social unrest events was the continuation of a longer trend since 2016 (Figure 1), which itself reversed a gradual decline in unrest following a peak after the Arab Spring of 2011.

\footnotetext{
${ }^{3}$ It may be possible that disasters (or handling thereof) are the true primitive cause of social unrest causing political disagreements to which the events are erroneously attributed. Anecdotal evidence suggests that this is not the case for 2019.
} 
Figure 1: Global unrest and mobility since 2016

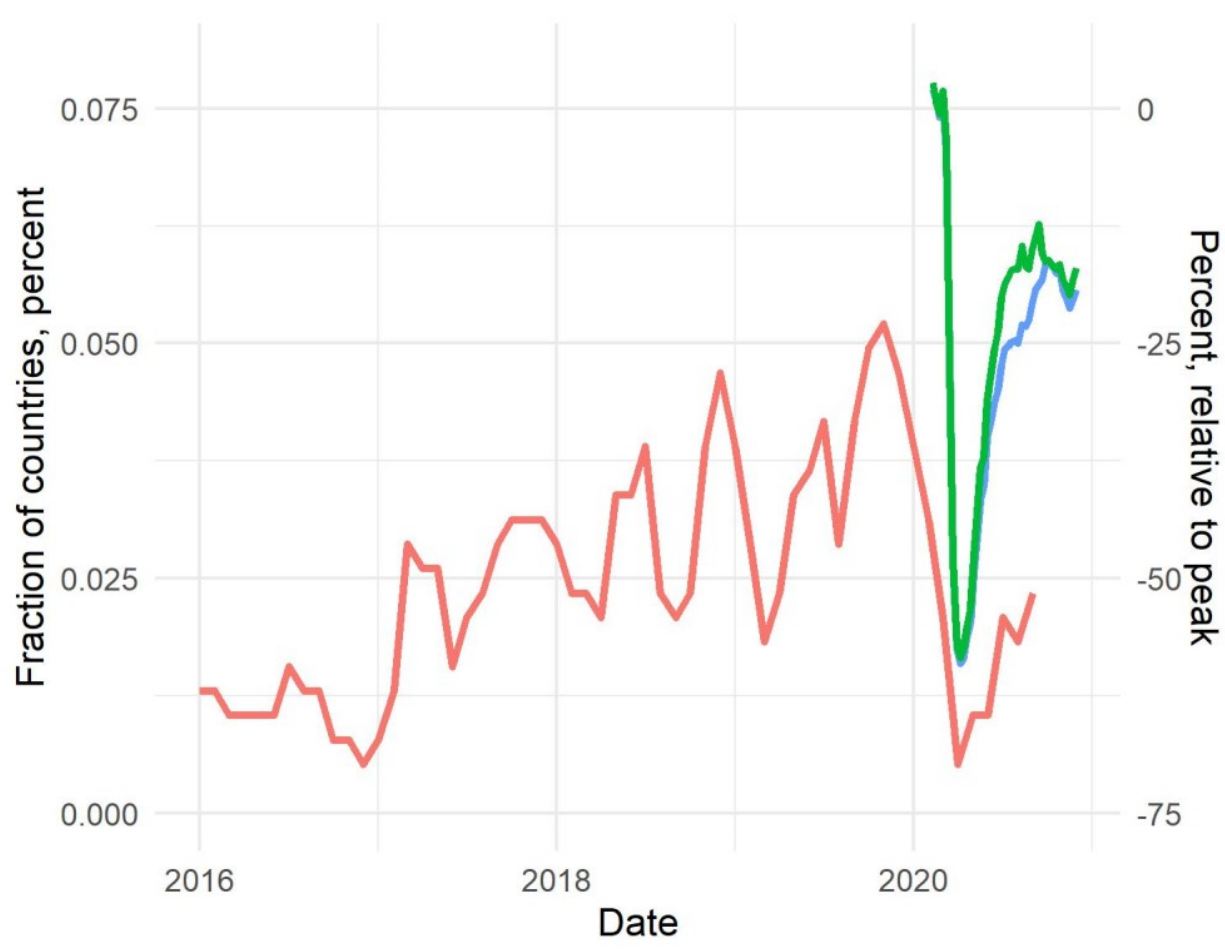

- Fraction of countries with social unrest events, 3-month rolling average (LHS)

- Google mobility data, retail \& recreation, weekly average (RHS)

- Google mobility data, transit stations, weekly average (RHS)

Source: Barrett et al. (2020), Google Community Mobility Reports and authors' calculations.

\section{Social unrest during COVID-19}

Since the start of the COVID-19 outbreak, the number of major unrest events worldwide has fallen sharply and in March reached its lowest level in almost five years (Figure 1). The decline in social unrest corresponds closely with a generalized decline in mobility driven by regulations such as shelter-in-place orders, and voluntary social distancing. To illustrate the remarkably close association between the timing of the decline in protest and the abrupt cessation of social activities, Figure 1 also includes global averages of two series from Google Community Mobility Reports. The mobility series use cell phone location history to measure activity in specific categories, of which we include two (activities in retail and recreation spaces and transit stations), although others look very similar. We interpret this time series correlation as suggestive evidence that mitigating effects of the latest epidemic 
have likely outweighed any scarring that might have incentivized unrest. We take up this question again more formally in the next section .

Notable exceptions to this pause in social unrest include the United States and Lebanon. Yet even in these cases, the largest protests were related to issues which long preceded the COVID-19 epidemic: racial injustice in the United States and governance in Lebanon.

The protests in the United States are a good test of the media-based approach to measuring unrest. An important challenge to our method is that media coverage of other high-profile issues, such as an ongoing pandemic, may "crowd out" the coverage of unrest. In Figure 2 we replicate the search criteria of Barrett et al. (2020) at a daily frequency for the United States. ${ }^{4}$ It shows that press articles related to unrest increase sharply at almost exactly the same time as major street protests broke out across the United States, despite a severe and continuing pandemic, suggesting that media coverage remains a good indicator of unrest even during a pandemic.

\footnotetext{
${ }^{4}$ Barrett et al. (forthcoming) similarly construct a daily social unrest index for a large sample of countries.
} 
Figure 2: Daily media mentions of unrest in the United States, early 2020

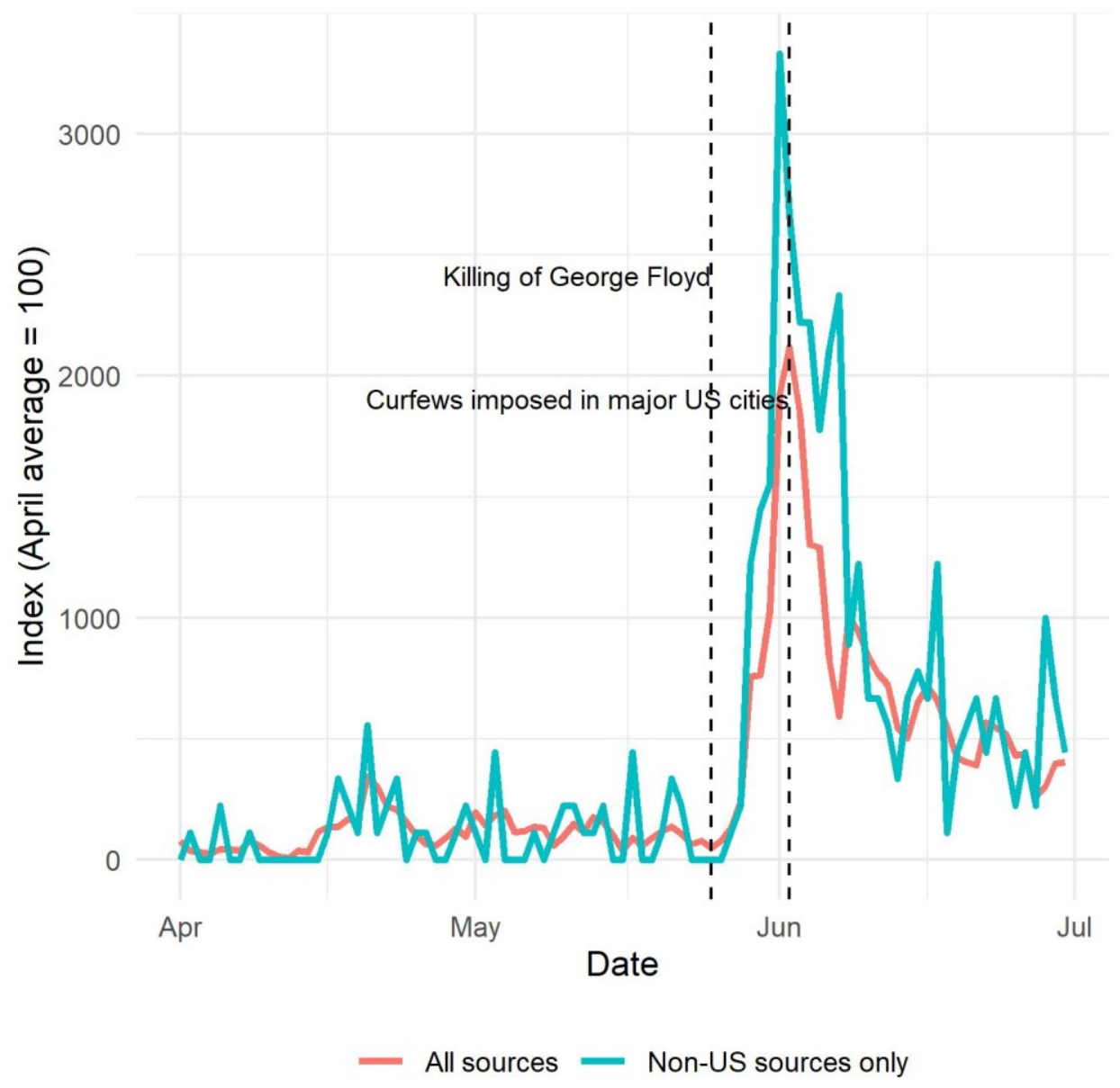

III. EMPIRICAL METHODOLOGY AND RESULTS

Here we analyze more formally the relationship between disasters and unrest. We report two main findings. First, there is a strong cross-sectional relationship in the data: countries with more disasters also have more unrest, even after accounting for variations in region, income, and exposure to waves of unrest. Second, there is a negative within-country relationship between epidemics and unrest, largest at around 4-6 months after the epidemic starts, consistent with the experience under COVID-19, but that other disasters show no obvious within-country intertemporal relationship with unrest.

We interpret this evidence as supporting two conclusions. The cross-country results are consistent with the notion that the permanent and pervasive risk of disasters could lead to 
more unrest on average. However, the within-country findings suggest that the realization of that risk - that is, the occurrence of disasters at a particular time — does not cause social unrest. If anything, epidemics are more likely to mitigate unrest than to spur it.

\section{A. Cross-sectional evidence}

We start by analyzing the cross-sectional relationship between disasters and unrest, asking whether countries have more epidemics have on average more social unrest. This relationship usefully captures long run and persistent variations across countries. This long-run perspective is important because epidemics may leave decades-long shadows in the society, as we alluded to in our earlier account of history of epidemics. However, the limitation of a cross-sectional analysis is its identification: there could be many factors causing a correlation between unrest and disasters.

Figure 3 plots the cross-sectional relationship between per capita disasters and unrest events for the six disaster types in our sample. ${ }^{5}$ In almost all cases, there is a positive relationship between unrest and disasters that is stable across income groups. Interestingly, the magnitude of the relationships is also relatively stable across the different types of disasters, despite considerable variation in the countries exposed to different disasters. ${ }^{6}$

The graphical evidence seems convincing. In the Appendix we check that this relationship is robust, reporting the results of the following regression:

$$
y_{i}=\alpha+\sum_{d} \beta x_{i, d}+\gamma_{r(i)}+v_{y(i)}+e_{i}
$$

where $i$ and $r$ index country and region respectively, $y_{i}$ is the log number of social unrest events per capita since 1990 in country $i, x_{i, d}$ is the log number of disasters, $e_{i r}$ is the error term, and $\gamma_{r(i)}$ and $v_{y(i)}$ are fixed effects for the region, $r(i)$, and income group, $\mathrm{y}(i)$, for

\footnotetext{
${ }^{5}$ The per capita measure accounts for the fact that large countries (typically) have more area in which natural disasters can occur, and more people who might want to engage in unrest. That said, our findings are almost identical without the per capita scaling.

${ }^{6}$ Of course, some countries are exposed to multiple disasters, but many are not. For example, earthquakes are relatively common in Japan, but droughts are rare there. The reverse is true in Niger.
} 
country $i$. With these controls, the coefficients of interest $\beta_{d}$ capture the relationship between disasters and unrest across countries within the same region and income group.

\section{Figure 3: Cross-sectional relationship between disasters and unrest}

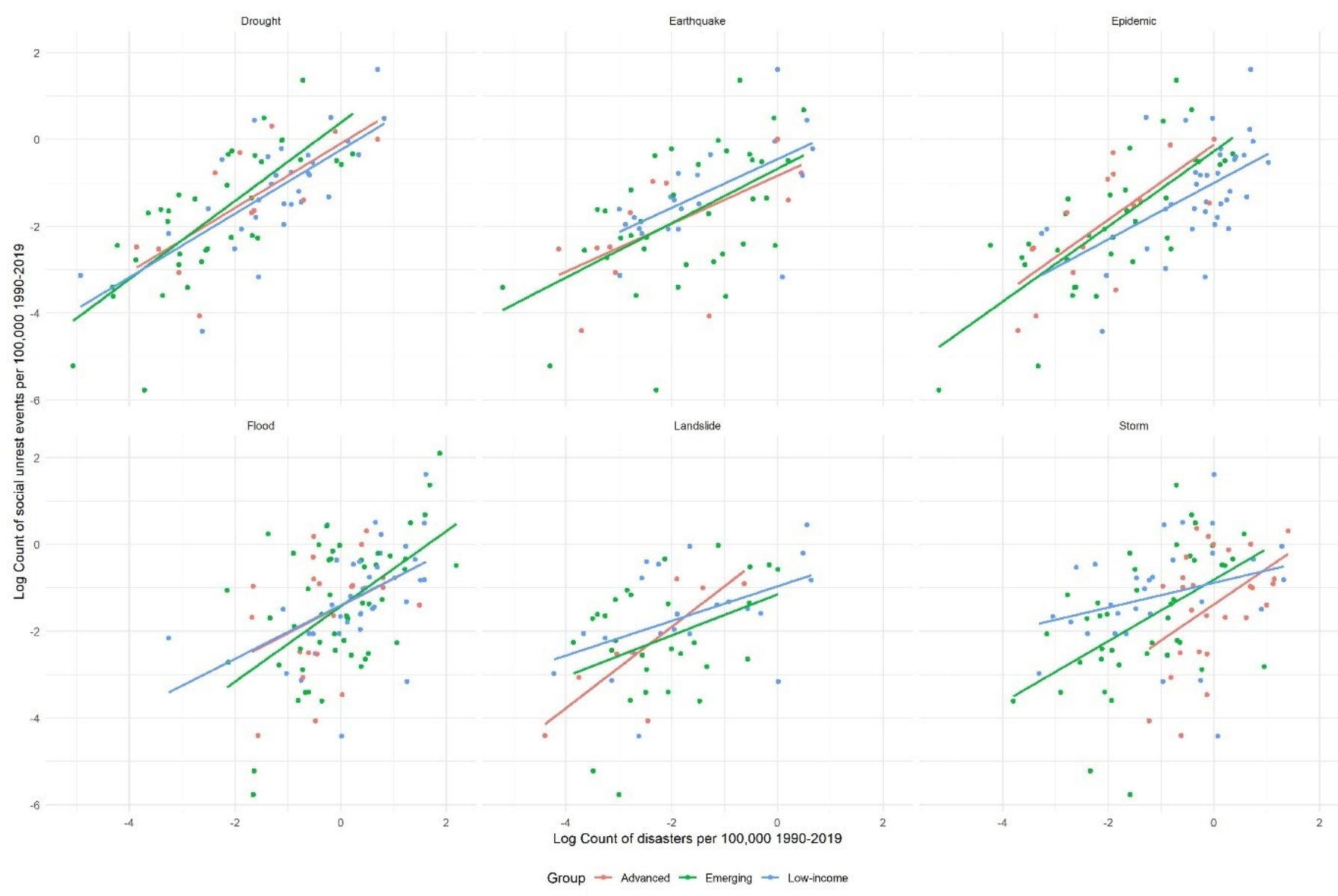

Source: Barrett et al. (2020), EM-DAT, and authors' calculations.

The results are reported in Table A2 and confirm the relationships in Figure 3. We find a positive and statistically significant cross-country relationship between disasters (all types combined) and social unrest (column (1)). The relationships for other types of disasters are statistically indistinguishable from each other (columns (2)-(4)) and are robust across regions and country income group.

Social unrest often occurs in regional waves, such as Arab Spring in 2011, or Latin American protests in 2019. Indeed, Barrett et al. (2020) show that recent social unrest both domestically 
and in neighboring countries is correlated with higher future social unrest. Likewise, disasters - particularly epidemics — are frequently regionally clustered. It thus seems plausible that the cross-sectional relationship is merely the result of coordinated waves of disasters and protest. To investigate this issue, we also estimate equation (1) using five-year averages within each country, including time fixed effects. The inclusion of time fixed effects accounts for global factors that may give rises to waves of unrest and disasters.

These results, reported in Table A2, columns (5) to (8), similarly show a robust and positive relationship between disasters and unrest. In fact, in many cases, this relationship is slightly stronger. The comparison now is across countries within a given five-year period, and so these results say that even in the medium run, countries with more disasters also have more unrest.

Overall, the cross-country evidence is relatively clear: there is a positive and strong relationship between natural disasters of all types and unrest. However, this does not necessarily mean that unrest is higher because of disasters. It could be that other factors, such as geography or institutions, induce a positive correlation between the two. To investigate the consequences of a disaster, we turn to the dynamic within-country behavior of unrest following a disaster next.

\section{B. Evidence from a dynamic panel}

Turn to the dynamic relationship between social unrest and disasters, we estimate the following panel regression, run separately for each type of disasters:

$$
y_{i t}=\alpha_{i}+\eta_{t}+\sum_{j=1}^{n} \beta_{j} x_{i t}^{j}+\gamma^{\prime} z_{i t}+e_{i t},
$$

where $y_{i t}$ is an indicator for a social unrest event in country $i$ in year $t, x_{i t}^{j}$ is an indicator variable that takes a value of 1 if the latest disaster event occurred $j$ months prior, $z_{i t}$ is a vector of controls, and $\alpha_{i}$ and $\eta_{t}$ are country and time fixed effects respectively. We use a linear probability so that we can include admit a wide battery of fixed effects - something much harder in a nonlinear framework. 
Note that this is slightly different from a local projection framework (Jordà 2005). There, one estimates separate regressions of $y_{i, t+h}$ on $x_{i t}$ and the set of controls over horizons $h=$ $0,1, \ldots, H$. The local projection approach is somewhat problematic in the current setting, simply because both unrest and disasters are rare, with unrest and epidemics occurring in around 1.2 and 1.9 percent of country-months respectively. Therefore, despite having a large sample, at any given horizon $h$ the probability of encountering many observations with both a disaster at time $t$ and an epidemic at time $h$ is very low. As a result, the local projection estimates have very low power, producing point estimates with very large standard errors.

A natural solution to this problem is to try to combine horizons to increase power. In the standard local projection framework this is impossible, as regressions at horizons $h$ and $h^{\prime}$ are complete separate objects, so there is no common variance-covariance matrix that can be used to compute standard errors. In the specification in equation (2), we have no such problem. We can easily estimate the coefficient on a horizon of, say, 4-6 months simply by replacing $x_{i t}^{j}$ with an indicator equals to 1 if the last disaster occurred 4, 5, or 6 months prior. This approach allows us to increase the power of our estimates while preserving the monthly frequency of the data.

Alternative ways of using the local projection framework exist, but they often require changing the interpretation of the coefficients. For example, using a rolling average for unrest would capture the probability of unrest up to horizon $h$ but inferring the probability of unrest in any given interval would be challenging. In comparison, the panel specification in equation (2) is simple and more transparent.

The dynamic panel regression approach is not without drawbacks. In particular, our point estimates are relative to some particular horizon after the disaster rather than the moment before it. We use more than 60 months after a disaster as the comparison horizon. This means that the coefficients measure the conditional average unrest likelihood in the short run (less than 5 years) relative to the period of 5 years or longer after a disaster occurred in the country. If there are permanent effects of disasters on unrest, this would bias our estimates downwards. However, Appendix Figure A1 suggests that such potential bias is quantitatively 
insignificant. There, we compare our results to the local projection equivalents. There is no evidence of a systemic difference on the point estimates between the two sets of results. Yet, the local projection estimates are much noisier than the panel estimates. Overall, this comparison supports the argument that the dynamic panel approach improves power without introducing noticeable biases.

We report the results for epidemics in Table 1. Column (1) is simply a baseline, reporting the average frequency of unrest events in the sample. Column (2) reports results of a simple dynamic specification. It shows a clear decline in the probability of unrest following an epidemic, with the effect peaks at 4-6 months. At its peak, the decline is sufficiently large as to almost entirely offset the average probability of unrest (a fall of 1.2 percent versus an average of 1.4 percent). This specification and all subsequent ones include country fixed effects and so abstract from the cross-sectional relationship discussed in the previous section, yielding a true dynamic response.

Other specifications add extra controls, including time since the last social unrest events in the same and neighboring countries, the intensity of the last epidemic, and time fixed effect. Our preferred specification is (3), which strikes a balance between fitting the data and preserving the sample. It also performs well on measures of fit-measured by Akaike Information Criterion and $\mathrm{R}^{2}$-of those without time fixed effects. Consistent with (2), it shows probability of unrest is lower during epidemic, with the effect peaks at 4-6 months. With the additional control, the effect on longer-horizons becomes smaller and statistically insignificant. ${ }^{7}$ Point estimates from the richer specifications (4-6) are broadly stable although the reduction in sample size (as some backward-looking variables are not available for all periods) leads to lower power. The inclusion of time fixed effects in column (6) likely absorb useful variation in epidemics, which can be correlated across countries even if exogenous.

\footnotetext{
${ }^{7}$ Although the long-run effect is small, is natural to expect that epidemics may indeed have some long-run effects, perhaps either because higher death rates can affect demographics for years to come, or because they are sufficiently traumatic that they have long-lasting psychological effects on the population.
} 
We perform the same exercise for other types of disasters and find much weaker evidence of a dynamic pattern. As an illustration, Table 2 presents the results for floods, the largest category of natural disasters. There is no statistically significant pattern, in contrast to epidemics. Results on other natural disasters are similar and omitted in the interest of space. What could explain this difference between natural disasters and epidemics? It could be that there is something unique about the contagious nature of epidemics and its suppressive force on protest and other forms of unrest, which are inherently social activities. Although natural disasters of all kinds likely impede protest movements by hampering transport, communications and the like, these challenges are likely less severe, more short-lived, and limited to the activity itself. In an epidemic, however, attending a large scale and possibly contagious event likely have serious and long-lasting consequence for the health of the participants (and those they meet), which may be a much higher deterrent to unrest.

Finally, a word on identification. While we do not advocate strongly for a causal interpretation, natural disasters are likely very close to randomly assigned (especially earthquakes and storms). For epidemics, its occurrence may be related to country-specific conditions. For example, country with worse health infrastructure may be less likely to prevent an epidemic. However, the specific timing of epidemics is likely random, particularly at the monthly level. This consideration on the timing of disasters informs our empirical design, which combines outcome horizons to increase power without losing the monthly frequency. Under this assumption, the effect of estimated in a tight window reflects a causal link.

What should we make of the empirical evidence overall? As discussed earlier, epidemics may have both scarring and mitigating effects on social unrest. Whether an epidemic will increase or decrease the overall likelihood of social unrest may depend on whether the scarring effect or the mitigating effect dominates over time. Our empirical results confirm this ambiguous relationship. On the one hand, the finding of a robust and positive crosssectional relationship between epidemics and social unrest is consistent with a long-run scarring effect. On the other hand, evidence is weak in the medium run. In the short run, the 
likelihood of social unrest is slightly lower following epidemics, consistent with the notion that the mitigating factors dominates in the short run.

Table 1: Impact of epidemics on unrest, linear probability model

\begin{tabular}{|c|c|c|c|c|c|c|}
\hline & \multicolumn{6}{|c|}{ Dependent variable: Indictor for social unrest event } \\
\hline & (1) & (2) & (3) & (4) & $(5)$ & (6) \\
\hline Epidemic, current month & & $\begin{array}{c}-0.011^{* * *} \\
(0.003)\end{array}$ & $\begin{array}{l}-0.009^{*} \\
(0.005)\end{array}$ & $\begin{array}{l}-0.008 \\
(0.006)\end{array}$ & $\begin{array}{l}-0.011^{*} \\
(0.006)\end{array}$ & $\begin{array}{l}-0.006 \\
(0.006)\end{array}$ \\
\hline Epidemic, last $1-3$ months & & $\begin{array}{c}-0.009^{* * *} \\
(0.003)\end{array}$ & $\begin{array}{l}-0.007 \\
(0.005)\end{array}$ & $\begin{array}{l}-0.008 \\
(0.006)\end{array}$ & $\begin{array}{l}-0.009 \\
(0.006)\end{array}$ & $\begin{array}{l}-0.006 \\
(0.007)\end{array}$ \\
\hline Epidemic, last 4-6 months & & $\begin{array}{c}-0.012^{* * *} \\
(0.003)\end{array}$ & $\begin{array}{l}-0.011^{* *} \\
(0.005)\end{array}$ & $\begin{array}{l}-0.010^{*} \\
(0.006)\end{array}$ & $\begin{array}{l}-0.010^{*} \\
(0.006)\end{array}$ & $\begin{array}{l}-0.006 \\
(0.006)\end{array}$ \\
\hline Epidemic, last 7-12 months & & $\begin{array}{l}-0.006^{* *} \\
(0.003)\end{array}$ & $\begin{array}{l}-0.001 \\
(0.004)\end{array}$ & $\begin{array}{l}-0.001 \\
(0.005)\end{array}$ & $\begin{array}{l}-0.001 \\
(0.005)\end{array}$ & $\begin{array}{c}0.003 \\
(0.005)\end{array}$ \\
\hline Epidemic, last 13-24 months & & $\begin{array}{c}-0.010^{* * *} \\
(0.003)\end{array}$ & $\begin{array}{c}-0.008^{* *} \\
(0.004)\end{array}$ & $\begin{array}{l}-0.008^{*} \\
(0.004)\end{array}$ & $\begin{array}{l}-0.010^{* *} \\
(0.005)\end{array}$ & $\begin{array}{l}-0.007 \\
(0.005)\end{array}$ \\
\hline Epidemic, last 25-60 months & & $\begin{array}{c}-0.006^{* * *} \\
(0.002)\end{array}$ & $\begin{array}{l}-0.002 \\
(0.003)\end{array}$ & $\begin{array}{l}-0.002 \\
(0.003)\end{array}$ & $\begin{array}{l}-0.003 \\
(0.003)\end{array}$ & $\begin{array}{l}-0.001 \\
(0.003)\end{array}$ \\
\hline Months since last social unrest event & & & $\begin{array}{l}-0.0004^{* * *} \\
(0.00003)\end{array}$ & $\begin{array}{l}-0.0004^{* * *} \\
(0.00004)\end{array}$ & $\begin{array}{l}-0.0004^{* * *} \\
(0.00004)\end{array}$ & $\begin{array}{l}-0.0004^{* * *} \\
(0.00004)\end{array}$ \\
\hline Months since last social unrest event, neighboring country & & & & $\begin{array}{c}0.00002 \\
(0.00005)\end{array}$ & $\begin{array}{c}0.00004 \\
(0.00004)\end{array}$ & $\begin{array}{c}0.00003 \\
(0.00004)\end{array}$ \\
\hline Deaths per capita in last epidemic & & & & & $\begin{array}{l}-0.0001^{* * *} \\
(0.00004)\end{array}$ & $\begin{array}{c}-0.0001^{* *} \\
(0.0001)\end{array}$ \\
\hline Constant & $\begin{array}{l}0.014^{* * *} \\
(0.001)\end{array}$ & & & & & \\
\hline Country FEs & No & Yes & Yes & Yes & Yes & Yes \\
\hline Time FEs & No & No & No & No & No & Yes \\
\hline Normalized AIC & -1.437 & -1.442 & -1.056 & -1.006 & -1.127 & -1.155 \\
\hline $\mathrm{R}^{2}$ & 0.014 & 0.019 & 0.05 & 0.051 & 0.049 & 0.075 \\
\hline Observations & 27,505 & 27,505 & 18,123 & 15,137 & 12,953 & 12,953 \\
\hline
\end{tabular}

Note: This table reports results of dynamic panel regressions. The dependent variable is a dummy variable that takes a value of 1 for social unrest events. Standard errors clustered at the country-month level are shown in parenthesis. 
Table 2: Impact of flood on unrest, linear probability model

\begin{tabular}{|c|c|c|c|c|c|c|}
\hline & \multicolumn{6}{|c|}{ Dependent variable: Social unrest event } \\
\hline & (1) & (2) & (3) & (4) & (5) & (6) \\
\hline Flood, current month & & $\begin{array}{l}-0.007^{*} \\
(0.004)\end{array}$ & $\begin{array}{l}-0.003 \\
(0.007)\end{array}$ & $\begin{array}{l}-0.004 \\
(0.008)\end{array}$ & $\begin{array}{c}0.001 \\
(0.009)\end{array}$ & $\begin{array}{c}0.003 \\
(0.009)\end{array}$ \\
\hline Flood, last 1-3 months & & $\begin{array}{l}-0.007^{*} \\
(0.004)\end{array}$ & $\begin{array}{l}-0.002 \\
(0.006)\end{array}$ & $\begin{array}{l}-0.006 \\
(0.007)\end{array}$ & $\begin{array}{l}-0.0004 \\
(0.007)\end{array}$ & $\begin{array}{l}-0.0001 \\
(0.008)\end{array}$ \\
\hline Flood, last 4-6 months & & $\begin{array}{l}-0.005 \\
(0.003)\end{array}$ & $\begin{array}{c}0.001 \\
(0.006)\end{array}$ & $\begin{array}{l}-0.003 \\
(0.007)\end{array}$ & $\begin{array}{c}0.002 \\
(0.007)\end{array}$ & $\begin{array}{c}0.002 \\
(0.008)\end{array}$ \\
\hline Flood, last 7-12 months & & $\begin{array}{l}-0.004 \\
(0.003)\end{array}$ & $\begin{array}{c}0.001 \\
(0.006)\end{array}$ & $\begin{array}{l}-0.002 \\
(0.007)\end{array}$ & $\begin{array}{c}0.004 \\
(0.008)\end{array}$ & $\begin{array}{c}0.004 \\
(0.008)\end{array}$ \\
\hline Flood, last 13-24 months & & $\begin{array}{l}-0.003 \\
(0.003)\end{array}$ & $\begin{array}{l}-0.001 \\
(0.006)\end{array}$ & $\begin{array}{l}-0.004 \\
(0.007)\end{array}$ & $\begin{array}{c}0.003 \\
(0.007)\end{array}$ & $\begin{array}{c}0.004 \\
(0.007)\end{array}$ \\
\hline Flood, last 25-60 months & & $\begin{array}{l}-0.006^{* *} \\
(0.003)\end{array}$ & $\begin{array}{l}-0.006 \\
(0.006)\end{array}$ & $\begin{array}{l}-0.009 \\
(0.006)\end{array}$ & $\begin{array}{l}-0.005 \\
(0.007)\end{array}$ & $\begin{array}{l}-0.003 \\
(0.007)\end{array}$ \\
\hline Months since last social unrest event & & & $\begin{array}{c}-0.0004^{* * *} \\
(0.00004)\end{array}$ & $\begin{array}{l}-0.0004^{* * *} \\
(0.00004)\end{array}$ & $\begin{array}{c}-0.0004^{* * *} \\
(0.00004)\end{array}$ & $\begin{array}{l}-0.0004^{* * *} \\
(0.00004)\end{array}$ \\
\hline Months since last social unrest event, neighbor & & & & $\begin{array}{c}0.00001 \\
(0.00004)\end{array}$ & $\begin{array}{c}0.00003 \\
(0.00004)\end{array}$ & $\begin{array}{c}0.00001 \\
(0.00003)\end{array}$ \\
\hline Deaths per capita in last epidemic & & & & & $\begin{array}{l}-0.0001^{* *} \\
(0.00003)\end{array}$ & $\begin{array}{c}-0.00005 \\
(0.0001)\end{array}$ \\
\hline Constant & $\begin{array}{c}0.013^{* * *} \\
(0.001)\end{array}$ & & & & & \\
\hline Country FEs & No & Yes & Yes & Yes & Yes & Yes \\
\hline Time FEs & No & No & No & No & No & Yes \\
\hline Normalized AIC & -1.487 & -1.49 & -1.077 & -1.013 & -1.125 & -1.15 \\
\hline $\mathrm{R}^{2}$ & 0.013 & 0.017 & 0.047 & 0.051 & 0.048 & 0.072 \\
\hline Observations & 36,143 & 36,143 & 23,175 & 19,033 & 16,242 & 16,242 \\
\hline
\end{tabular}

Note: This table reports results of dynamic panel regressions. The dependent variable is a dummy variable that takes a value of 1 for social unrest events. Standard errors clustered at the country-month level are shown in parenthesis.

\section{Conclusion}

This paper examines the implications of epidemics on social unrest using global evidence in recent decades. Drawing on a new cross-country dataset of social unrest, we find a positive cross-sectional relationship between social unrest and epidemics. While this result may reflect a positive long-run effect, we find that the relationship reverses in the short run. This difference between the long-run and short-run result suggest are consistent with the theoretical prediction on the scarring and mitigating effects of epidemics. 
Recent trends in social unrest immediately before and after the COVID-19 outbreak are also consistent with this historic evidence. Unrest was elevated before the COVID-19 crisis began but has declined as the pandemic has continued. If history is a guide, it is reasonable to expect that, as the pandemic fades, unrest may reemerge in locations where it previously existed, not because of the COVID-19 crisis per se, but simply because underlying social and political issues have not been tackled. 


\section{References}

Aisen, Air and Francisco Veiga, 2013, "How Does Political Instability Affect Economic Growth?” European Journal of Political Economy, 29:151-167.

Alesina, Alberto and Perotti, Roberto, 1996, "Income Distribution, Political Instability, and Investment”. European Economic Review, 40(6):1203-1228.

Alesina, Alberto, Sule Özler, Nouriel Roubini, and Philip Swagel, 1996, "Political Instability and Economic Growth", Journal of Economic Growth, 1:189-211.

Barrett, Philip, Maximiliano Appendino, Kate Nguyen, and Jorge de Leon Miranda, 2020, Measuring Social Unrest Using Media Reports, IMF Working Paper 20/129.

Barrett, Philip, Mariia Bondar, Sophia Chen, Mali Chivakul, Deniz Igan, forthcoming, Social Unrest and Financial Markets, IMF Working Paper.

Bernal-Verdugo, Lorenzo E., Davide Furceri, and Dominique Guillaume, 2013, The Dynamic E_ect of Social and Political Instability on Output: The Role of Reforms. IMF Working Paper No. 13/91.

Bristow, Nancy, 2017, American Pandemic: The Lost Worlds of the 1918 Influenza Epidemic, Oxford University Press.

Cervellati, Matteo, Uwe Sunde, and Simona Valmori, 2017, "Pathogens, Weather Shocks and Civil Conflicts", The Economic Journal, 127(607), Pages 2581-2616.

Cervellati, Matteo, Elena Esposito, Uwe Sunde, and Simona Valmori, 2018, “Long-term Exposure to Malaria and Violence in Africa", Economic Policy, 33(95), Pages 403-446.

Collier, P., A. Hoeffler and D. Rohner, 2009, "Beyond Greed and Grievance: Feasibility and Civil War", Oxford Economic Papers, No. 61, Pages 1-27.

Deverell, William F., 2004, Whitewashed Adobe the Rise of Los Angeles and the Remaking of Its Mexican Past. University of California Press.Elledge, Jonn, 2020, "Revolts and Revolutions: How History Reveals the Ways Coronavirus Could Change Our World Forever”, Prospect, April 17, 2020.

Fearon, J.D. and D.D. Laitin, 2003, "Ethnicity, Insurgency, and Civil War", American Political Science Review, No. 97, Pages 75-90.

Gonzales-Torres, Ada and Elena Esposito, 2017, Epidemics and Conflict: Evidence from the Ebola outbreak in Western Africa, mimeo.

Hogarth, Rana A., 2017, Medicalizing Blackness Making Racial Difference in the Atlantic World, 1780-1840, The University of North Carolina Press.International Monetary Fund (IMF), 2020a, World Economic Outlook, Chapter 1: Global Prospects and Policies Global Prospects and Policies, Box 1.4.

International Monetary Fund (IMF), 2020b, World Economic Outlook, Chapter 2: Dissecting the Economic Effects.

Jong-A-Pin, Richard, 2009, "On the Measurement of Political Instability and Its Impact on Economic Growth”, European Journal of Political Economy, 25:15-29. 
Jordà, Òscar, 2005, "Estimation and Inference of Impulse Responses by Local Projections", American Economic Review, 95(1):161-182.

Miguel, Edward, Shanke Satyanath, and Ernest Sergenti, 2004, "Economic Shocks and Civil Conflict: An Instrumental Variables Approach", Journal of Political Economy, 112(4), Pages 725-753.

North, Douglass C. and Robert Paul, 1973, The Rise of the Western World: A New Economic History, Cambridge University Press.

Ponticelli, Jacopo and Hans-Joachim Voth, 2020, "Austerity and Anarchy: Budget Cuts and Social Unrest in Europe, 1919-2008", Journal of Comparative Economics 48 (1), Pages 1-19.

Randall, David K., 2010, Black Death at the Golden Gate: The Race to Save America from the Bubonic Plague, W. W. Norton \& Company.

Snowden, Frank M., 2019, Epidemics and Society: From the Black Death to the Present, Yale University Press. 


\section{Appendix}

Table A1: EM-DAT disasters since 1990 (with at least 50 observations)

\begin{tabular}{lccccc}
\hline Type & Number & Avg Deaths & Avg affected & $\begin{array}{c}\text { Avg Damage } \\
\text { (USD) }\end{array}$ & $\begin{array}{c}\text { Avg Mortality } \\
(\%)\end{array}$ \\
\hline Flood & 4096 & 48 & 751467 & 187812 & 0.01 \\
Storm & 2942 & 139 & 321082 & 483299 & 0.04 \\
Epidemic & 1235 & 163 & 18993 & 0 & 0.86 \\
Earthquake & 819 & 1007 & 173415 & 903272 & 0.58 \\
Landslide & 523 & 50 & 13025 & 15187 & 0.39 \\
Extreme temperature & 522 & 335 & 198391 & 105692 & 0.17 \\
Drought & 472 & 51 & 3671603 & 322349 & 0.00 \\
Wildfire & 340 & 6 & 19438 & 366170 & 0.04 \\
Volcanic activity & 155 & 16 & 48054 & 14949 & 0.03 \\
\hline
\end{tabular}


Table A2: Cross-section regressions

\begin{tabular}{|c|c|c|c|c|c|c|c|c|}
\hline & \multicolumn{8}{|c|}{ Dependent variable: Log number of social unrest events 1990-2019 } \\
\hline & (1) & (2) & (3) & (4) & $(5)$ & (6) & (7) & (8) \\
\hline Log number of disasters, per capita & $\begin{array}{c}0.515^{* * *} \\
(0.034)\end{array}$ & & & & $\begin{array}{l}0.793^{* * *} \\
(0.028)\end{array}$ & & & \\
\hline Log number of droughts, per capita & & $\begin{array}{c}0.434^{* * *} \\
(0.063)\end{array}$ & $\begin{array}{c}0.411^{* * *} \\
(0.057)\end{array}$ & $\begin{array}{c}0.418^{* * *} \\
(0.058)\end{array}$ & & $\begin{array}{c}0.626^{* * *} \\
(0.037)\end{array}$ & $\begin{array}{c}0.626^{* * *} \\
(0.037)\end{array}$ & $\begin{array}{l}0.624^{* * *} \\
(0.037)\end{array}$ \\
\hline Log number of earthquakes, per capita & & $\begin{array}{l}0.466^{* * *} \\
(0.063)\end{array}$ & $\begin{array}{c}0.454^{* * *} \\
(0.058)\end{array}$ & $\begin{array}{l}0.457^{* * *} \\
(0.058)\end{array}$ & & $\begin{array}{l}0.745^{* * *} \\
(0.041)\end{array}$ & $\begin{array}{l}0.745^{* * *} \\
(0.041)\end{array}$ & $\begin{array}{l}0.748^{* * *} \\
(0.041)\end{array}$ \\
\hline Log number of epidemics, per capita & & $\begin{array}{c}0.590^{* * *} \\
(0.067)\end{array}$ & $\begin{array}{c}0.573^{* * *} \\
(0.061)\end{array}$ & $\begin{array}{c}0.573^{* * *} \\
(0.062)\end{array}$ & & $\begin{array}{c}0.714^{* * *} \\
(0.039)\end{array}$ & $\begin{array}{c}0.714^{* * *} \\
(0.039)\end{array}$ & $\begin{array}{l}0.715^{* * *} \\
(0.038)\end{array}$ \\
\hline Log number of floods, per capita & & $\begin{array}{c}0.723^{* * *} \\
(0.147)\end{array}$ & $\begin{array}{c}0.758^{* * *} \\
(0.137)\end{array}$ & $\begin{array}{c}0.743^{* * *} \\
(0.136)\end{array}$ & & $\begin{array}{c}0.968^{* * *} \\
(0.048)\end{array}$ & $\begin{array}{c}0.968^{* * *} \\
(0.048)\end{array}$ & $\begin{array}{l}0.967^{* * *} \\
(0.048)\end{array}$ \\
\hline Log number of landslides, per capita & & $\begin{array}{l}0.499^{* * *} \\
(0.071)\end{array}$ & $\begin{array}{c}0.480^{* * *} \\
(0.065)\end{array}$ & $\begin{array}{l}0.481^{* * *} \\
(0.065)\end{array}$ & & $\begin{array}{l}0.771^{* * *} \\
(0.040)\end{array}$ & $\begin{array}{l}0.771^{* * *} \\
(0.040)\end{array}$ & $\begin{array}{l}0.773^{* * *} \\
(0.040)\end{array}$ \\
\hline Log number of storms, per capita & & $\begin{array}{c}0.490^{* * *} \\
(0.083)\end{array}$ & $\begin{array}{c}0.505^{* * *} \\
(0.077)\end{array}$ & $\begin{array}{c}0.526^{* * *} \\
(0.079)\end{array}$ & & $\begin{array}{c}0.784^{* * *} \\
(0.039)\end{array}$ & $\begin{array}{c}0.784^{* * *} \\
(0.039)\end{array}$ & $\begin{array}{c}0.788^{* * *} \\
(0.039)\end{array}$ \\
\hline Constant & $\begin{array}{c}-0.974^{* * *} \\
(0.066)\end{array}$ & $\begin{array}{c}-1.003^{* * *} \\
(0.070)\end{array}$ & $\begin{array}{c}-0.983^{* * *} \\
(0.087)\end{array}$ & $\begin{array}{c}-1.291^{* * *} \\
(0.202)\end{array}$ & $\begin{array}{c}-0.942^{* * *} \\
(0.067)\end{array}$ & $\begin{array}{c}-0.962^{* * *} \\
(0.084)\end{array}$ & $\begin{array}{c}-0.962^{* * *} \\
(0.084)\end{array}$ & $\begin{array}{c}-0.935^{* * *} \\
(0.136)\end{array}$ \\
\hline Regression type & $\mathrm{x}$-sect & $\mathrm{x}$-sect & $\mathrm{x}$-sect & $\mathrm{x}$-sect & 5-yr panel & 5-yr panel & 5-yr panel & 5-yr panel \\
\hline Region FEs & No & No & Yes & Yes & No & Yes & Yes & Yes \\
\hline Time FEs & No & No & No & No & No & No & Yes & Yes \\
\hline Income group FEs & No & No & No & Yes & No & No & No & Yes \\
\hline Observations & 504 & 504 & 504 & 504 & 795 & 795 & 795 & 795 \\
\hline $\mathrm{R}^{2}$ & 0.281 & 0.291 & 0.363 & 0.368 & 0.503 & 0.585 & 0.585 & 0.592 \\
\hline Adjusted $\mathrm{R}^{2}$ & 0.280 & 0.282 & 0.350 & 0.354 & 0.503 & 0.580 & 0.580 & 0.584 \\
\hline
\end{tabular}

Note: This table reports results of cross-sectional (columns 1-4) and 5-year panel (columns 5-8) regressions. The dependent variable is the log number of social unrest events over the 1990-2019 period. Robust standard errors shown in parenthesis. 
Figure A1: Dynamic regressions versus local projections

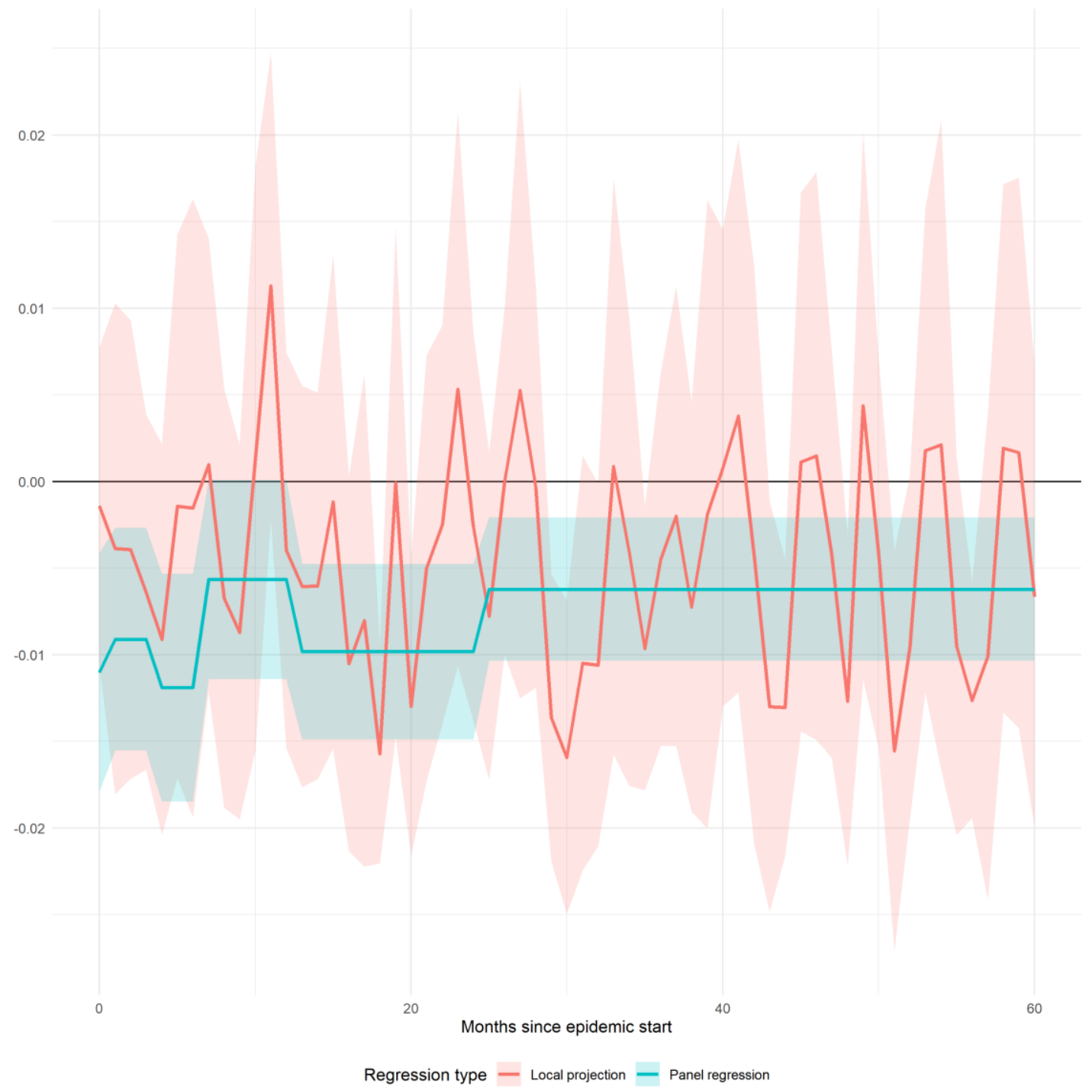

Note: This figure plots the point estimates and 90 percent confidence intervals of local projection and panel regression models. Source: Barrett et al. (2020), EM-DAT, and authors' calculations. 